\title{
Teachers' Emotional Intelligence and Sense of Self-efficacy Beliefs: A study on Second Cycle Public Primary School EFL Teachers in Bahir Dar Town, Ethiopia
}

\author{
Girma Wossenie
}

Department of English Language and Literature, Bahir Dar University, Post Box No: 79, Bahir Dar, Ethiopia

\begin{tabular}{|c|c|}
\hline Abs & Ie Intor \\
\hline \multirow{13}{*}{$\begin{array}{l}\text { The purpose of this study was to examine second cycle public primary school English as } \\
\text { Foreign Language (EFL) teachers' level of emotional intelligence (EI) and self-efficacy beliefs } \\
\text { and the relationship between the two constructs. Forty-three randomly selected EFL teachers } \\
\text { were taken as a sample of the study. To generate data and answer the research questions, } \\
\text { the researcher adapted two questionnaires - EFL teachers' El and self-efficacy beliefs - from } \\
\text { two separate sources and the instruments were checked for their reliability and validity. Data } \\
\text { generated through the administration of the questionnaires were analyzed by using one } \\
\text { sample t-test and Pearson Product Moment Correlation Coefficient. The results of the study } \\
\text { indicated that EFL teachers' El and self-efficacy beliefs were found low as the observed } \\
\text { means trailed far behind from the expected means in all the major categories of the two } \\
\text { constructs. However, significant and strong relationship was found between EFL teachers' El } \\
\text { and sense of self-efficacy beliefs. In conclusion, the participants fell short off the expected } \\
\text { levels of El and self-efficacy beliefs, albeit an iota of the constructs was observed. Following } \\
\text { the shift in orientation from teacher-centered to student-centered curriculum which underpins } \\
\text { the application of communicative-based English textbooks, the two constructs are suggested } \\
\text { to be incorporated both in EFL teacher preparation and professional development programs } \\
\text { so as to address both cognitive and affective side of the target language learning and } \\
\text { teaching. }\end{array}$} & listory: \\
\hline & Received : 21-03-2014 \\
\hline & Revised \\
\hline & Accepted : 20 \\
\hline & Key \\
\hline & \\
\hline & acy beliefs \\
\hline & \\
\hline & Pub \\
\hline & \\
\hline & sponding Author: \\
\hline & \\
\hline & \\
\hline
\end{tabular}

\section{INTRODUCTION}

Based on communicative language teaching (CLT), The Ministry of Education in Ethiopia has introduced communicative-based textbooks and disseminated them to the schools throughout the country a couple of years ago. The purpose of developing the new textbooks was to replace the structural approach that failed to create a room for students' use of the target language in a real world communication. The newly introduced textbooks are supposed to address the inability of the structural approach to foster student communicative competence.

CLT anchored in communicative competence model consists of grammatical, sociolinguistic and strategic competences. Grammatical competence involves fostering student knowledge of language features, including vocabulary, word and sentence formations, and spelling. Sociolinguistic competence considers developing students' ability to use appropriate spoken and written language, whereas strategic competence involves enhancing student communication strategies to overcome their communication problems (Canale and Swain, 1980).

Besides implementing CLT and its component, another important terrain in helping student get involved in communicative interaction is to engage EFL teachers in an exploration of their emotional sates and self-efficacy levels that inform their classroom practice (Richards, 1998).

At present, the roles of teachers are becoming extremely challenging and formidable at all levels of teaching. Many teachers not only face heavy workloads and time pressure in their daily teaching activities, but also have to cope with rampant students' discipline problems and pressure from parents and administration (Brotheridge and Grandey, 2002). In an attempt to manage these stressors, teachers may need to have abilities such as being able to motivate themselves and persist in the face of frustrations or adversities; to control impulse and delay gratification; to regulate one's moods and keep distress from engulfing or swamping the ability to think; to empathize and to hope (Goleman, 1995). Wubbels and Levy (1991) claim the existence of a strong relationship between teachers' affective traits and learners' emotional developments.

Similarly, EFL classroom teaching in Ethiopian context is increasingly becoming difficult as the students' target language abilities are reportedly deteriorating from time to time which is also coupled with rampant discipline problems, EFL teachers need to consider their levels of emotional intelligence and self-efficacy as a new 
specialized dimension to tackle the difficulties they face in EFL classrooms and devise strategies to help foster effective language learning and teaching.

By way of drawing inference from the foregoing paragraphs one may consider that if the academic process (knowledge acquisition, maintenance, application, reflection and evaluation) overshadows the affective process, creating successful target language learning context would seem to be in a stake.

The argument posed by different scholars in language teaching and learning show that some students learn a second/foreign language easily and some with considerable difficulty. This argument appears to be cogent that there are many factors affecting second/foreign language learning success, among which the degree of self-efficacy and emotional intelligence (EI) that teachers have at their disposal recently gained research attention. Research conducted on the $\mathrm{EI}$ demonstrated that there was a significant relationship between this construct and success in many areas, including teaching (Ghanizadeh and Moafian, 2010), learning (Brackett and Mayer, 2003), and academic success (Gil-Olarte, Palomera, and Brackett, 2006). In a similar vein, the findings of research on self-efficacy, the beliefs individuals hold about their capabilities to complete a task successful (Bandura, 1997), proved the facilitative nature self-efficacy plays in teaching, learning and academic achievement (Pajares, 1996; Schunk and Meece, 2005).

When dealing with the affective side of language learners, attention needs to be given both to how we can overcome problems created by negative emotions and how we can create and use more positive, facilitative emotions. Needless to say that in the presence of overly negative emotions such as anxiety, fear, stress, anger or depression, students' optimal learning is likely to be compromised. The most innovative techniques and the most attractive teaching materials may be rendered inadequate, if not useless, by negative affective reactions involved with the language learning process (Arnold, 1999). However, stimulating the different positive emotional factors such as self-esteem, empathy or motivation can greatly facilitate the language learning process. This implies that language teachers should be aware of the importance of both negative and positive emotional factors and of ways to handle them.

In a social constructivist theory of learning what the individual does construct personal meaning. As opposed to static views of the learner as a passive element in the process, constructivism applied to language learning would consider learners as actively involved in making their own sense of the language input that surrounds them as well as the tasks presented to them (Williams and Burden, 1997). In this model emotions play an integral part in the teaching learning process. Moreover, Stern (1983) explains how affective components contribute much more to language learning than cognitive skills.

Stevick (1980) contends that successful language learning depends less on materials, techniques, and linguistic analysis, and more on what goes on inside and among the students and the teacher. This brings us to the importance of affect for what occurs in the classroom can be seen in the shift in the dominant metaphor for teaching
/ learning process from transmission to dialogue. Dialogue involves people- thinking and feeling, spiritual and physical beings in negotiating meaning (Arnold, 1999).

Success in language learning is inextricably linked to the way in which learners experience the classroom, which is a place where learners with different intellects and emotional status come together to acquire, maintain and use the language. Accordingly, teachers' emotional intelligence is of key importance to discern various negative emotions that incapacitate learners' from reaching their learning potential (Purkey, 1970; Gurney, 1987).

Currently, there is a shift in focus from the teacher to the learner. The shift considers the necessity of creating learning situations or opportunities in which inhibition and barriers are lowered so that communication can take place in a more effective manner. In EFL teaching context, the teacher is supposed to integrate the cognitive and the affective side of leaning. Arnold and Brown (1999) argue that the affective side of learning is not in contravention with the cognitive side. The authors further note that when both are used together the learning process can be constructed on a firmer foundation. It is at this stage that efficacious and emotionally intelligent EFL teachers play important roles in leading their students towards significant language learning and emotional growth.

It is also the contention of the present researcher that in meaningful and interactive EFL classrooms, affective and cognitive learning coexist and work together in a tandem or in a reciprocal manner nurturing each other. In fact, interest in affective factors in education is not a new phenomena and there is a long- standing controversy surrounding the role that each play in the curriculum of formal education. The controversy attempts to draw a distinction between affective learning and cognitive learning by suggesting that the former has to do with emotions and feelings while the latter to do with the mental functions involved in thinking, knowing, and understanding the subject matter. However, in recent years such controversies are dying out in favor of integrating the affective and cognitive learning, and teaching and learning in EFL classrooms cannot be different (Arnold, 1998).

More importantly, as it is known by many language teaching and researching scholars in recent years, the Communicative Language Teaching (CLT) has placed a pervasive influence on language teaching in all its phases (syllabus design, materials writing and development, teaching techniques, etc.) and CLT gives its due recognition to affective learning in a more conspicuous manner (Stevick, 1976; Richards and Rodgers. 1986). That means EFL classroom participations in the decision making process opens up greater possibilities for students to develop their whole potential both academically and emotionally which in turn results in a life-long learning. In other words, In addition to the language content, students also learn responsibility, negotiation skills and selfevaluation, all of which lead to greater self-esteem and self-awareness and developing and growing as a whole person (Tudor, 1977; Williams and Burden, 1997; Brundage and MacKeracher, 1980; Nunan, 1988). 


\section{Girma Wossenie}

In language classroom which focuses on meaningful interaction, there is certainly a room for dealing with the affect side of leaning. What inference can be drawn from this is that the relationship between affect and language learning is a bidirectional one. Attention to affect, which subsumes the idea of self-efficacy and emotional intelligence, can improve language teaching and learning.

The underlying contention is that self-efficacious and emotionally intelligent EFL teachers can create a congenial target language learning and teaching. Therefore, the idea of self-efficacy beliefs and emotional intelligence needs to at the disposal of EFL teachers where they can be put to use in the classroom so as to bring the desired learning and teaching outcome.

The emotional intelligence concept is based on the premise that emotions and cognitions shape each other (Mesquita, Frijda and Scherer, 1997). That means teachers' emotions can influence the way they think, solve problems, and develop self-efficacy beliefs. In other words, emotional intelligence can influence beliefs about teaching, which in turn determine effective teaching and student teaching (Anderson, 2004).

In the ensuing sections, the researcher discusses the concept of $\mathrm{El}$, self-efficacy and the relationship between the two constructs in EFL contexts.

Anchoring in Thorndike's (1920) idea of social intelligence and in Gardner's (1983) Theory of Multiple Intelligences, Salovey and Mayer (1990) developed the concept of Emotional Intelligence (EI). The pioneers in EI, Salovey and Mayer, defined it as the ability to recognize one's own and others' feelings and emotions, to discriminate among them and to use this information to guide one's thinking and actions. Later on, Bar-On (1997) defined El as a cross-section of interrelated emotional and social competencies, skills and facilitators that determine how effectively we understand and express ourselves, understand others and relate with them, and cope with daily demands.

El is a thriving concept in the field of education because one of the most essential features of being a teacher and teaching is the emotional relationships that teachers have with their students in the process of teaching and learning. Teaching and learning are not only concerned with knowledge, cognition and skill. They are also emotional practices which can obviously influence the process either positively or negatively. Teachers can create interest in their students or bore them, be approachable or standoffish with parents, trust their colleagues or be suspicious of them. All teaching is therefore inextricably emotional- by design or fault (Hargreaves, 2000). Teachers feel negative emotions, such as frustration (Hargreaves, 2001), anxiety (Erb, 2002), and helplessness (Kelchtermans, 1996). They also feel different positive emotions, such as love and affection (Godar, 1990), joy, satisfaction and pleasure. In other words, teachers who have high emotional competencies are likely to develop a positive rapport with their students, which in turn has an impact on students' learning and achievement. Therefore, the way in which emotions are understood, reflected, and managed may hold promise in effective teaching. The overarching natures of teachers' emotions not only affect their teaching, but also influence
Sci. Technol. Arts Res. J., April-June 2014, 3(2): 213-220

the way they think and develop efficacy beliefs concerning teaching.

Efficacy is the belief in one's ability to carry out the necessary actions to achieve a certain desired outcome (Bandura, 1997). This means that one's sense of efficacy affects personal feelings, thoughts and motivations. People with higher efficacy possess a high quality of decision making. On the other hand, people with low efficacy give up quickly, have low aspirations for achievement, and experience anxiety, which causes stress and burnout (Gibson and Dembo, 1984).

In educational contexts, where teachers have to meet teaching demands, teacher efficacy could be an important personal resource in coping with job stress. As a result, teacher self-efficacy is 'the teacher's belief in his or her capability to organize and execute courses of action required to successfully accomplishing a specific teaching task in a particular context' (Tschannen-Moran, WoolfolkHoy and Hoy, 1998, Pp, 233).

Studies on teacher efficacy have provided evidence of the significance of the role of efficacy on teachers' behavior. Findings indicate that teachers" efficacy beliefs not only have considerable influence on their instructional practices and classroom behavior but also have formative effects on their students' achievement and motivation (Goddard, Hoy and Woolfolk-Hoy, 2004). In this regard, teachers with high efficacy beliefs manage negative affective experiences better than teachers with low efficacy beliefs who may succumb to anxiety. Moreover, highly efficacious teachers are more sensitive to the needs of students, are more enthusiastic in their teaching (Allinder, 1994), and are more willing to work efficiently with students who have behavior problems (Hoy and Woolfolk, 1990).

Ross (1994, p. 345) analyzed 88 teachers' efficacy levels and concluded that highly efficacious teachers are willing to:

(1) Learn and use new approaches and strategies for teaching, (2) use management techniques that enhance student autonomy and diminish student control, (3) provide special assistance to low achieving students, (4) build students' self perceptions of their academic skills, (5) set attainable goals, and (6) persist in the face of student failure.

In short, theoretical views in the literature indicate that self-efficacy is influenced by several factors, one of which is the individual's emotional states (Bandura, 1986). As a result, it seems cogent to envisage the likelihood of a relationship between EFL teachers' EI and self-efficacy, and conduct a local research on the topic.

Moreover, there is a growing body of literature that Emotional Intelligence and Self-efficacy exist together and interact with each other (Drew, 2006). Bandura (1997) linked the role of efficacy to concepts of emotional intelligence throughout his pioneering work. He argued that self-awareness and control of emotions can be correlated with higher self-efficacy levels. Chan (2008) in his study investigated teacher efficacy and emotional intelligence as personal resources for active and passive coping strategies among Chinese pre-service and inservice teachers in Hong Kong. It was concluded that 


\section{Girma Wossenie}

emotional intelligence and teacher efficacy contributed to coping strategies such as behavioral or psychological responses designed to change the nature of the stressor itself or how one thinks about it. The findings of these studies indicate that people who have higher control of their emotions develop stronger efficacy, and this leads to higher El. Put it simply, El may contribute to teaching through its influence on beliefs about teaching. The teacher with high efficacy and El will demonstrate effective teaching behaviors in the classroom that enhance students' motivation to learn and to participate in leaning activities (Bandura, 1997).

Another important research was conducted by Rastegar and Memarpour (2009) who assessed the relationship between emotional intelligence and selfefficacy among Iranian EFL teachers. The findings indicated that there was a positive significant correlation between perceived El and self-efficacy. The researchers also found that there was no significant difference among EFL teachers with different genders, ages and teaching experiences regarding their $\mathrm{El}$ and self-efficacy.

Although there are a number of oversea researches on El and self-efficacy, the present researcher argues that conducting further research on the topic would seem to be cogent to draw firm conclusions or to challenge the issue from different angle in our local EFL context. In other words, there is a dearth of research in this area which may curtail new insights and development in teaching and learning the target language at different levels in Ethiopian educational system.

Current researchers in the area of language learning and teaching have shown us the indispensable nature of focusing more on language learners and their experience rather than simply on the subject matter knowledge. It is the experience of every EFL teacher nowadays to help the target language learners get involved in a variety of communicative tasks where a great deal of vulnerability exists as the learners trying to express themselves before their peers and their teachers in a shaky oral and written English communication.

In communicative language teaching classrooms, students have to spend a considerable amount of time to complete language learning tasks. Interactive and meaningful target language communication cannot take place if care is not taken to create an emotional safe classroom environment. It is the experience of every EFL teachers in our context that there is a great deal of vulnerability in the target language classrooms where students grapple with expressing themselves before their peers and their teachers by using shaky and weak English language skills -oral and written communication. Such vulnerability obstructs the target language learning process by creating anxiety which is associated with negative emotions such as uneasiness, frustration, selfdoubt, apprehension, and tension. The presence of negative emotions in EFL classrooms can contribute to poor academic performance. As a result, EFL teachers' recognition and beliefs to handle the different nature of emotions in their classrooms would enable them to intervene at the right time and with a clear purpose so as to consciously facilitate both individual and group target language learning.
Sci. Technol. Arts Res. J., April-June 2014, 3(2): 213-220

In this regard, the elements of active learning such as critical thinking and problem solving both of which require learners involvement cannot take place effectively if emotional security is in a state of limbo (Williams and Burden, 1997). It is possible to argue at this juncture that intellect and emotion are inseparably linked and anchored in the process of active learning and overlooking one in support of the other in the target language classroom would be counterproductive. In other words, EFL teachers' emotional intelligence and self-efficacy beliefs play an important role in promoting active learning through proper treatment of intellect and emotion.

As EFL teachers, we cannot absolutely expect our classrooms to be pleasant and crammed with inspiring environment that the time spent there is a constant source of success and satisfaction for teachers and students alike. There is always a strong likelihood that a considerable number of students may be, bored, hostile, uncomprehending, or simply shun learning the target language as intended. To respond to such difficulties, one may argue that EFL teachers should be in a position to invest a great variety of repertoires of knowledge, skills, beliefs, emotional literacy, etc in creating successful language learning.

In other words, the target language teachers are required to have the necessary resources at their disposal to minimize any negative emotion-provoking conditions that can inhibit the academic process. Resources like teachers' Emotional Intelligence and self-efficacy beliefs are getting special attentions in recent years (Mayer and Salovey, 1990; Goleman, 1995; Bandura, 1997;) as one of the agents to facilitate effective and meaningful language teaching and learning.

As language teachers come to know themselves better- by keeping abreast of current developments in their area of specialization- they will also be able to understand their students better and lead them towards more significant learning and growth (Arnold, 1999). To put it in another way, EFL teachers have to deal with students who come to class with diverse abilities, inabilities and with a range of emotional tendencies.

Although the concepts of EFL teachers' El and selfefficacy beliefs are examined in different oversea researches, the present researcher would like to argue that there is no such research endeavor in our context. Therefore, studying EFL teachers Emotional Intelligence and self-efficacy beliefs may put a new complexion in creating new understanding in the process making informed-decisions about the target language learning and teaching. To this end, the following research questions are formulated to be answered in the process of this study.

1. What are the public primary school second cycle EFL teachers' self-efficacy beliefs?

2. What are the EFL teachers' emotional intelligence competency levels?

3. Is there any relationship between EFL teachers' EI and their sense of self-efficacy?

Based on the three questions posed above, the researcher attempted to identify EFL teachers' sense of self-efficacy beliefs and their emotional intelligence levels. The study also assessed the relationship between EFL 
teachers' self-efficacy and emotional intelligence due to the fact that there is a plethora of new oversea research findings' illustrating the importance of the two constructs in target language teaching and learning. To this end, the present research examined the two constructs separately and then appraised their relationships in a local EFL context.

These days in Ethiopia, EFL teaching profession is facing formidable challenges from different perspectives, such as the changes in demographic nature of the student population, the emergence of advanced technology in language education, and the introduction of new education polices, etc. all of which require highly competent teachers who can apply a complex range of cognitive and emotional skills and knowledge to create the kind of active learning set in the curriculum. To respond to the multifaceted EFL classroom teaching, EFL teachers' focus on students' cognitive processing of the target language alone is not enough if attention is not paid to the part played by the emotions in perception, negotiation and decision making. Besides this, teachers' sense of self-efficacy is one of the essential elements to respond to the growing challenges in EFL classroom teaching that teachers call upon when they teach. Richards (1998) delineates teaching as a dynamic process characterized by constant change. This brings the idea of $\mathrm{El}$ and self-efficacy to the fore for due consideration when teachers make decisions that are appropriate to the specific dynamics of the lesson they are teaching

The concept of Teacher IE and self-efficacy is gaining considerable research attention suggesting promising positive results to support EFL teaching and learning. As a result, target language teaching experts. EFL curriculum developers, English language teacher educators, and professionals working with EFL teacher professional development programs in Ethiopia should think about how the concept can be put into practice. Moreover, the shift in focus from teacher training to teacher education requires teachers in developing their own theories of teaching, in understanding the nature of classroom decision making, and in developing strategies for critical self-awareness and self-evaluation (Richards and Nunan, 1990). This shift in orientation would seem to subsume the role of El and self-efficacy in teacher preparation programs, and ELT cannot be exceptional.

This study examined EFL teachers' sense of selfefficacy beliefs and El competency levels. It also looked into the relationship between EFL teachers' Emotional Intelligence and self-efficacy levels of 43 public second cycle primary school EFL teachers found in Bahir Dar Town, Ethiopia. It did not address the participants' gender, age and teaching experiences. Furthermore, further research on the topic seems to be tenable to see how the concept can interact with other variables of knowledge involved in EFL teaching, such as teaching skills, communication skills, and pedagogical reasoning and decision making, and teacher cognition in general.

\section{MATERIALS AND METHODS}

\section{Method of the Study}

From different quantitative research methodologies, the researcher used the descriptive survey strategy to interpret the data.

\section{Population and Sampling}

Public primary school second cycle EFL teachers were the target population of this study. In Bahir Dar town there are 33 primary schools. Out of these, 28 were second cycle (grades 5-8) schools. A total of $84 \mathrm{EFL}$ teachers were teaching in the second cycle and 43 of them were selected for the study by using simple random sampling techniques.

\section{Instruments}

Two instruments were used to generate the necessary data for the research. Emotional Intelligence Questionnaire developed by Smith, (n.d) was adapted and used to measure the research participants' EI. The EI profile chart has 16 scales and was adapted to gauge different aspects of EFL teachers' El. The El comprises four items (perceiving emotions, using emotions, understanding emotions, managing emotions) and each item has four sub-scales:

1. Perceiving Emotions (Self-analysis, Analysis of others, Self-expression, Discrimination),

2. Using Emotions (Thinking, Judgment, Sensitivity, Problem solving),

3. Understanding Emotions (Symptoms, causes, Complexity, Transitions), Managing Emotions (Openness, Monitoring, Self-control, Managing Others). The reliability of the IE scale estimated through Cronbach's alpha coefficient and was found 0.86 .

Another instrument to generate data for the study was the short version of Teachers' Sense of Self-efficacy Scale (TSES) developed by Tschannen- Moran and Woolfolk-Hoy (2001). The TSES was used because it encompasses the essential elements required to elicit the necessary data for the research in a succinct manner. It comprises 12 items including four items for each of the three subscales: Efficacy in student engagement; Efficacy in instructional strategies; Efficacy in classroom management. The items used to measure how much an individual EFL teacher can do concerning efficacy for engagement, efficacy for management, and efficacy for using instructional strategies.

The reliability of the efficacy scale estimated through Cronbach's alpha coefficient and was found 0.78 . Descriptive and Inferential statistics were used to analyze and interpret the data by using the software package SPSS version 16 .

\section{RESULTS}

To analyze and interpret the EFL teachers' EI competencies and self-efficacy beliefs, the researcher used inferential statistics for the scores on overall EFL teachers' efficacy levels and overall El competencies

One sample t-test analysis was conducted to examine the Emotional Intelligence of EFL teachers who were in the study. The results in table 1 showed that the observed means for El competencies of the teachers who participated in the study were below the expected means for all the four major components of El: perceiving emotions, using emotions, understanding emotions and managing emotions. 
Table 1: One sample t-test on Emotional Intelligence (IE)

\begin{tabular}{lclcccc}
\hline \multicolumn{1}{c}{ El Categories } & No. of Items & Ob. Mean & Exp. mean & sd & df & Sig. \\
\hline Reading/Perceiving Emotions & 4 & 12.23 & 22 & 2.09 & 42 & 0.000 \\
Using Emotions & 4 & 12.62 & 22 & 1.96 & 42 & 0.000 \\
Understanding Emotions & 4 & 11.33 & 22 & 1.74 & 42 & 0.000 \\
Managing Emotions & 4 & 12.26 & 22 & 2.24 & 42 & 0.000 \\
\hline
\end{tabular}

The results in Table 2 revealed the comparison between the observed and the expected means of primary school second cycle EFL teachers' self efficacy beliefs vis-à-vis the three main components of self efficacy levels: Efficacy for student engagement, Efficacy for classroom management and Efficacy for instructional strategy use.
Similar results were found concerning the observed means which were significantly far below the expected means in all the variables. That is, primary school EFL teachers have low self efficacy beliefs concerning student engagement, classroom management and the use of instructional strategies in their EFL classrooms.

Table 2: One sample t-test on Self Efficacy

\begin{tabular}{lcccccc}
\hline Self-Efficacy Categories & No. of Items & Ob. Mean & Exp. mean & sd & df & Sig. \\
\hline Student Engagement & 4 & 10.59 & 22 & 1.60 & 42 & 0.000 \\
Classroom Management & 4 & 12.50 & 22 & 1.81 & 42 & 0.000 \\
Instructional Strategies & 4 & 11.46 & 22 & 1.93 & 42 & 0.000 \\
\hline
\end{tabular}

The correlation analysis in Table 3 indicated the existence of important relationships among the different variables of Emotional Intelligence and self-efficacy levels of the research participants. Reading emotions is highly and significantly correlated with using emotions, understanding emotions, managing emotions, efficacy for engagement, efficacy for classroom management and efficacy for instructional strategies. Using emotions as one variable of emotional intelligence also significantly correlate with all self efficacy categories, engagement, classroom management and instructional strategies. In similar vein, understanding emotions and managing emotions correlate with the three self efficacy components.

Table 3: Correlation among Categories of Emotional Intelligence and Self Efficacy

\begin{tabular}{|c|c|c|c|c|c|c|c|}
\hline El Categories & & & & & & & \\
\hline Reading Emotions & $1.000^{\star *}$ & & & & & & \\
\hline Using Emotions & $0.091^{*}$ & $1.000^{\star *}$ & & & & & \\
\hline $\begin{array}{l}\text { Understanding } \\
\text { Emotions }\end{array}$ & $0.071^{*}$ & $0.132^{*}$ & $1.000^{\star *}$ & & & & \\
\hline Managing Emotions & $0.118^{*}$ & $0.0304^{* *}$ & $0.223^{*}$ & $1.000^{\star *}$ & & & \\
\hline $\begin{array}{c}\text { Student Engagement } \\
\text { Efficacy }\end{array}$ & $0.081^{*}$ & $0.365^{\star *}$ & $0.344^{\star *}$ & $0.171^{*}$ & $1.000^{\star *}$ & & \\
\hline $\begin{array}{c}\text { Classroom } \\
\text { Management Efficacy }\end{array}$ & $0.209^{*}$ & $0.076^{*}$ & $0.075^{\star}$ & $0.103^{*}$ & $0.122^{*}$ & $1.000^{\star *}$ & \\
\hline $\begin{array}{c}\text { Instructional } \\
\text { Strategies Efficacy } \\
\end{array}$ & $0.098^{*}$ & $0.082^{*}$ & $0.079^{*}$ & $0.170^{*}$ & $0.120^{*}$ & $0.180^{*}$ & $1.000^{* *}$ \\
\hline Categories & $\begin{array}{c}\text { Reading } \\
\text { Emotions }\end{array}$ & $\begin{array}{c}\text { Using } \\
\text { Emotions }\end{array}$ & $\begin{array}{l}\text { Understanding } \\
\text { Emotions }\end{array}$ & $\begin{array}{l}\text { Managing } \\
\text { Emotions }\end{array}$ & $\begin{array}{c}\text { Student } \\
\text { Engagement }\end{array}$ & $\begin{array}{c}\text { Classroom } \\
\text { Management }\end{array}$ & $\begin{array}{c}\text { Instructional } \\
\text { Strategies }\end{array}$ \\
\hline
\end{tabular}

\section{DISCUSSION}

The present study investigated the relationship between EFL teachers' Emotional Intelligence and their sense of self-efficacy. The study was conducted in second cycle primary schools found in Bahir Dar Town Administration, Ethiopia. In this section the responses derived from data analysis have been summarized and presented in a succinct manner to address the three research questions posed in this study.

Research Question 1: This study sought to investigate, in the first place, EFL teachers' level of emotional intelligence. The results indicated diminished levels of EFL teachers' sense of emotional intelligence as shown in Table 1. However, there is a growing body of research findings that emotionally intelligent teachers can create effective classroom learning and teaching. Mortiboys,
(2005) showed that creating emotional enhancing learning environment will promote the likelihood of learners' satisfaction, motivation and cooperation.

In a similar vein, Kremenitzer (2005, p. 7) argued that "Being able to regulate and manage emotions within the classroom is an important factor for effective and successful teaching". Major implications came out from the studies (Drew, 2006; Olarte, Palomera, and Brackett, 2006; Rastegar and Memarpour, 2009) demonstrated the need to incorporate emotional literacy into the educational curriculum. English language learning and teaching is a complex processes in a context where the target language is not a mother tongue. This implies that both the teacher and the students come to the classroom with considerable emotional status in which their emotions, if not regulated and used appropriately, can derail the type of active leaning intended to take place. 
Research Question 2: Regarding the second research question - EFL teachers' sense of self-efficacy levels- the results indicated that the efficacy levels of the teachers in the study fell short of the expected means in all the three variables as illustrated in Table 2. Nevertheless, in EFL classroom teaching there are a number of opportunities and impediments following the shift in orientation from teacher-fronted classroom to student-centered classroom. In this case, the EFL teachers' high sense of self-efficacy beliefs are required to make use of the opportunities and to overcome the hurdles in creating meaningful and interactive language learning.

Although weak teachers' self-efficacy beliefs were observed in this study, many research findings showed that the higher the teachers' self-efficacy perception levels, the higher their students' academic achievement levels would be (Chambers and Hardy, 2005; Ross, 1998). To give prominence to the preceding ideas, Good and Brophy, (2003) also contended that teachers with higher levels of self-efficacy perception maintained higher levels of students' participation.

The foregoing ideas about the importance of selfefficacious teacher in creating meaningful classroom learning and teaching is consistent with Woolffolk and Hoy, (1990) research findings which showed that teacher self-efficacy is one of the most important variables consistently related to positive and effective teaching and student learning outcomes. What inference that can be drawn at this juncture from this study is that the flickering self-efficacy beliefs that EFL teachers hold may require some urgent attention.

Research Question 3: Concerning the relationship between EFL teachers' El competencies and their sense of self-efficacy levels, the study indicated that there was a positive strong relationship between $\mathrm{El}$ and self-efficacy levels (Table 3 ). The findings of current study accorded with those reported by Rasteger and Memarpour, (2009); Chan, (2004) and Martin et al. (2004).

This correlation means that EFL teachers' IE competencies and self-efficacy beliefs have the potential to be developed and nurtured since each has a positive influence on the other. The two constructs, IE and selfefficacy categories, have much in common that they influence each other which in turn opens the way for improving classroom teaching competence.

In other words, either self-directed or school-based professional development programs can create a room for raising EFL teachers' self-efficacy beliefs and their IE competencies. At this juncture it may be possible to pose an argument that the inclusion of the two constructs in EFL teacher professional development programs may put a new complexion in helping the teachers to make informed pedagogical decisions in their classroom teaching.

\section{CONCLUSIONS}

Based on the results of the present study, the researcher may conclude that EFL teachers', who participated in this study, rated themselves below the expected means for the two overall categories of Emotional Intelligence and self-efficacy beliefs. However, research findings confirmed that the two constructs have an overarching influence on creating successful teaching and learning environment, and EFL classroom teaching and learning where the teacher organizes and facilitates communicative interactions, gives attention to proper balance between fluency and accuracy etc cannot be an exceptional for active learning to occur.

Since teachers' IE and self-efficacy beliefs belong to high inference categories, they exert a considerable amount of influence on the process of critical thinking, problem solving, decision making etc in EFL classrooms. As a result, the development of teacher IE competencies and self-efficacy beliefs deserve due consideration in both EFL teacher preparation programs and on job teacher professional development programs that can help raise and bring the desired outcomes of learning -academically and emotionally. Goleman (1995) contended that EI competencies can be taught and developed in teachers and in students and similar argument was posed by Salovey and Mayer (1990) in their pioneering work about El. Concerning self-efficacy beliefs of teachers, Bandura (1997) stated the same contention that it can be fostered both in teachers and in students so as to improve success in learning and teaching.

In other words, teacher educators are suggested to make teachers in preparation familiar with the concept of efficacy and the importance of teachers' IE competencies in their pedagogical performance and achievement. Similarly, school-based EFL teacher professional development programs identify teachers' efficacy beliefs and IE competency levels and find ways how to integrate the constructs with academic process so as to foster the growth of positive emotion and cognition in the target language learning.

\section{REFERENCES}

Anderson, L. (2004). Increasing Teacher Effectiveness. UNESCO International Institute for Educational Planning. http://unesdoc.unesco.org/images/0013/001376/137629e. pdf. Retrieved 15 November, 2013.

Arnold, J. (1998). Towards more Humanistic Language Teaching. ELT Journal 52(3): 235-242.

Arnold, J. and Brown, H. D. (1999). A map of the terrain. In: Arnold, J. (Ed.), Affect in Language Learning. Cambridge: Cambridge University Press.

Bar-On, R., (1997). The Emotional Quotient Inventory (EQ-I): Technical Manual, Multi-Health Systems. Toronto, Canada.

Bandura, A., (1997). Self-efficacy: The exercises of control. W.H. Freeman and Company, New York.

Brackett, M.A., and Mayer, J.D. (2003). Convergent, discriminant, and incremental validity of competing measures of emotional intelligence. Personality and Social Psychology Bulletin 29(9): 1147-1158.

Brotheridge, C. and Grandey, A. (2002). Emotional labor and burnout: Comparing two perspectives of pepole work'. Journal of Vocational Behavior 60: 17-39.

Brundage, D. and MacKeracher, D. (1980). Adult Learning Principles and their Application to Program Planning. Ontario Institute for Studies in Education.

Canale, M. and Swain, M. (1980). Theoretical bases of communicative approaches to second language teaching and testing. Applied Linguistics I(I):1-47. 
Girma Wossenie

Chan, D.W., (2004). Perceived emotional intelligence and self-efficacy among Chinese secondary school teachers in Hong Kong. Personality and Individual Differences 36(8): 1781-1795.

Chan, D.W., (2008). Emotional intelligence, self-efficacy, and coping among Chinese prospective and in-service teachers in Hong Kong. Educational Psychology 28(4):397-408.

Chambers, S.M. and Hardy, J.C. (2005). Length of time in student teaching: Effect on Classroom Control Orientation and Self-efficacy Beliefs. Educational Research Quarterly 28(3):3-9.

Drew, T. (2006). The relationship between emotional intelligence and student teacher performance. Unpublished PhD dissertation, University of Nebraska.

Erb, C.S. (2002). The emotional whirlpool of beginning teachers' work. Paper presented at the annual meeting of the Canadian Society of Studies in Education, May, 2002, Toronto.

Gardner, R.C.( 1985). Frames of mind: The theory of multiple intelligences. New York: Basic Books.

Ghanizadeh, A. and Moafian, F. (2010). The role of EFL teachers' emotional intelligence in their success. ELT Journal 64(4): 424-435.

Gibson, S. and Dembo, M. (1984). Teacher efficacy: A construct validation. Journal of Educational Psychology 76:569-582.

Gil-Olarte, P., Palomera, R., Brackette, M.A. (2006). Relating emotional intelligence to social competence \& academic achievement in high school students. Psicothema18: 118 123.

Godar, J. (1990). Teachers' talk. Macombn, IL: Glenbridge Publishing.

Goddard, R.D., Hoy, W.K. and Woolfolk-Hoy, A. (2004). Collective efficacy beliefs: Theoretical Developments, empirical evidence, and future directions. Educational Research 33(3):3-12.

Good, T.L. and Brophy, J.E. (2003). Looking in Classroom ( $9^{\text {th }}$ ed.). Boston:Allyn Bacon.

Goleman, D. (1995). Emotional intelligence. New York: Bantam Books.

Gurney, P. (1987). Self-esteem Enhancement in Children: A review of Research Findings. Educational Research 29.

Hargreaves, A. (2000). Mixed Emotions: Teachers' Perceptions of their Interactions with Students. Teaching and Teacher Education 16: 811-826.

Hargreaves, A. (2001). Emotional geographies of teaching Teachers' College Record 103(6): 1056-1080

Hoy, W.K. and Woolfolk, A.(1990). Socialization of student teachers. American Educational Research Journal 27(2): 279-300.

Kelchtermmans, G. (1996). Teacher vulnerability: Understanding its moral and political roots. Cambridge Journal of Education 26: 307-324.

Kremenitzer, J.P. (2005).The emotional intelliegent early childhood educator: self reflective journaling. Early Childhood Education Journal 33(1): 3-9.

Mesquita, B., Frijda, N.H. and Schere, K.R. (1997). Culture and Emotion. In Handbook of Cross-cultural Psychology: Vol 2. Basic process and Human Development, (Eds,). J.
Sci. Technol. Arts Res. J., April-June 2014, 3(2): 213-220

Berry, P.R. Dean, and T.S. Saraswathi, 255-297. Boston: Allyn and Bacon.

Nunan, D. (1988). The learner-centered curriculum. Cambridge: Cambridge University Press.

Pajares, F. (1996). Self-efficay beliefs in academic settings. Review of Educational Research 66(4): 543-578.

Purkey, W. (1970). Self-concept and School Achievement. New York: Prentice Hall.

Rastegar, M. and Memarpour, S. (2009). The relationship between emotional intelligence and self-efficacy among Iranian EFL teachers. System Journal 37: 700-707.

Richards, J.C. (1998). Beyond training. Cambridge. Cambridge University Press.

Richards, J. and Rodgers, T. (1986). Approaches and methods in language teaching. Cambridge: Cambridge University Press.

Richards, J.C. and Nunan, D. (1990). Second Language Teacher Education, (Eds.), Cambridge: Cambridge University Press.

Ross, J.A. (1998). The antecedents and consequences of teacher efficacy. In: J. Brophy (Ed.), Research on teaching (Vol.7,pp.49-74). Greenwich, CT: JAI Press.

Thorndike, E.L. (1920). Intelligence and its uses. Harper's Magazine 140: 227-235.

Tschannen-Morgan, M. and Woolfolk Hoy, A. (2001). Teacher efficacy: Capturing an elusive construct. Teacher and Teacher Education 17: 783-805.

Tschannen-Morgan, M. and Woolfolk Hoy, A. (1998). Teacher efficacy: its meaning and measure. Review of Educational Research 68(2): 202-248.

Tudor, I. (1997). Learner-centeredness as Language Education. Cambridge: Cambridge University Press.

Salovey, P., and Mayer, J.D. (1990). Emotional Intelligence. Imagination, Cognition and Personality 9: 185-211.

Schunk ,DH, and Meece,JL. (2005). Self-efficacy beliefs of adolescents. UK: Information Age Publishing.

Smith, J. (n.d). Emotional Intelligence Questionnaire. McKenzie Consulting. www.mckpeople.com.au

Stern, H.H. (1983). Fundamental Concepts of Language Teaching. Oxford: Oxford University Press.

Stevick, E. W. (1976). Memory, Meaning and Methods. Rowley, MA: Newbury House.

Stevick,E. (1980). Teaching Languages: A Way and Ways. Rowley, MA: Newbury House.

Williams, M. and R.L. Burden. (1997). Psychology for Language Teachers. Cambridge: Cambridge University Press.

Woolfolk, A.E. and Hoy, W.K. (1990). Prospective Teachers' sense of Efficacy and Beliefs about Control. Journal of Educational Psychology 82:81-91.

Wubbles, T. and Levy, J. (1991). A comparison of interpersonal behavior of Dutch and American teachers. International Journal of Intercultural Relations 15: 1-18. 